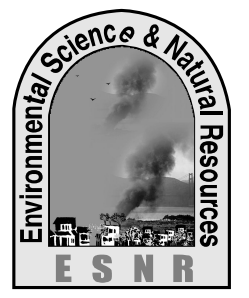

J. Environ. Sci. \& Natural Resources, 5(1): 267-272, 2012

ISSN 1999-7361

\title{
Effect of Sowing Patterns and Nitrogen Rates on Quality Traits and Yield of Wheat
}

\author{
M. S. Alam \\ Dept. of Agronomy and Agricultural Extension, University of Rajshahi, Rajshahi
}

\begin{abstract}
The experiment was conducted to study the effect of sowing patterns and $\mathrm{N}$ rates on quality traits and yield of wheat. The experiment consisted of two methods of sowing viz.; conventional sowing $\left(\mathrm{S}_{1}\right)$ and bed sowing $\left(\mathrm{S}_{2}\right)$ and four wheat varieties namely; Protiva $\left(\mathrm{V}_{1}\right)$, Sourav $\left(\mathrm{V}_{2}\right)$, Shatabdi $\left(\mathrm{V}_{3}\right)$ and Prodip $\left(\mathrm{V}_{4}\right)$ and four levels of nitrogen viz; $0\left(\mathrm{~N}_{1}\right), 60\left(\mathrm{~N}_{2}\right), 110\left(\mathrm{~N}_{3}\right)$ and $160\left(\mathrm{~N}_{4}\right) \mathrm{kg} \mathrm{N}^{-1}$. Grain yield was higher in bed planting system than conventional one due to improvement in yield components. Grain yield was increased with increasing rates of nitrogen application. Prodip produced the highest grain yield with $160 \mathrm{Kg} \mathrm{N} \mathrm{ha}{ }^{-1}$. The highest grain yield was found with the combination of bed sowing method and $160 \mathrm{Kg} \mathrm{N}^{-1}$ and the lowest one was recorded with the combination of conventional method at control treatment. Nitrogen and Protein content in grain and straw varied significantly due to method of sowing. The highest nitrogen and protein content in grain and straw were recorded in bed planting system. Nitrogen content of grain was highest at $160 \mathrm{Kg} \mathrm{N}$ $\mathrm{ha}^{-1}$.The overall results indicate that among the varieties Prodip showed better performance in bed planting system. Prodip gave maximum grain yield at $160 \mathrm{Kg} \mathrm{N} \mathrm{ha}^{-1}$ in bed planting system.
\end{abstract}

Key words: Nitrogen, Protein, Wheat, Yield

\section{Introduction}

The common wheat (Triticum aestivum L.) is a hexaploid $(2 \mathrm{n}=6 \mathrm{x}=42)$ belongs to the family Gramineae and is a worldwide popular grain crop. Wheat is one of the leading cereal crops and ranks first both in area and production in the world. In Bangladesh it is the second staple food crop next to rice having an annual production of 7.72 lakh tons and total area of 4.81 lakh hectares (DAE, 2006). The yield of wheat in the farmers' field is much lower than that in the research farm (Anon., 1990). The yield of $w$ heat depends on many factors such as varieties and suitable agronomic practices. Among the agronomic practices, nitrogenous and boron fertilizer application, sowing dates and sowing method are important factors in determining the yield of wheat.Variety plays an important role in producing high yield of wheat. Different varieties respond differently for their genotypic characters, input requirement, growth process and the prevailing environment during growing season. The growth process of wheat plants under a given agro-climatic condition differs with variety (Anon.,1999). Bangladesh has a number of modern varieties of wheat namely Sourav, Shatabdi, Prodip, Bijoy etc. Number of tillers, number of spikelets, spike length, grain size, grain yield and other yield contributing characters differ from one variety to another. Planting method is one of the important factor which affects wheat yield. Raised bed is widely used in developed countries as an improved system of productivity. The system was originally developed in Mexico's Yaqui
Valley, where more than $90 \%$ of farmers have adopted the practice. It is extensively used in wheat growing areas in Mexico from the last decade (Meisner et al., 1992 ). Crop establishment using bed planting system is a new technique in farming system of Bangladesh. Bed sowing holds immense potential for improving irrigated wheat-based cropping systems by making them less resource intensive and more sustainable. This technique offers new and better weed control, water management and fertilizer management opportunities, along with less crop lodging and some reduction in tillage (Sayre, 2003). It increases crop yield by $10-20 \%$ with the proper variety, saves 30-40\% irrigation water, reduces seed rate, promotes higher nitrogen use efficiency, reduces production cost over the conventional system (BARI, 2006). There are indications that yields of wheat on beds can be further increased through nitrogen applications because of the reduced loss of lodging on beds. Bed sowing helps to control soil erosion, reducing soil compaction and bettering soil physical structure over time. Additionally, once the beds are established there are new opportunities to reduce crop turn-around time by re-using the same bed without tillage (Sayre, 2003).

Plants require several nutrient elements for their normal growth and development. Among different nutrient element nitrogen is the most important plant nutrient needed to obtain high wheat yield as well as other crops. Nitrogen has beneficial effect in increasing wheat yield. The effect of nitrogen is more prominent and distinct over other fertilizers. Nitrogen 
is the integral part of protoplasm, protein and chlorophyll and results in increasing cell size, which in turn increases plant height and crop yield. Nitrogen application increases seed yield (Samad et al., 1984). Increasing levels of nitrogen increases the grain yield (Singh and Singh, 1989). Nitrogen fertilizer has significant effect on producing higher grain yield (Ahmed and Hossain, 1992). When the nitrogen supply is limited leaf enlargement, tillering, internode elongation, flowering, grain formation and other such development are adversely affected. But in case of wheat production, farmers of Bangladesh do not pay enough attention to the use of an optimum $\mathrm{N}$ level. While majority of the farmers are generally not aware and not willing to use fertilizers, there is an urgent need to educate them on its optimal application and efficient use to derive maximum benefit. Optimal fertilization is a prerequisite for obtaining higher yield. Considering the above information, the present experiment was undertaken to study the effect of sowing patterns and $\mathrm{N}$ rates on quality traits of wheat.

\section{Materials and Methods}

The present research work was carried out at Agronomy Field Laboratory, Department of Agronomy and Agricultural Extension, University of Rajshahi during the period from November 2006 to April 2007 to study the effect of sowing methods and nitrogen levels on quality traits and yield of wheat. The experiment consisted of two methods of sowing viz.; conventional $\left(\mathrm{S}_{1}\right)$ and bed planting $\left(\mathrm{S}_{2}\right)$, four wheat varieties namely; Protiva $\left(\mathrm{V}_{1}\right)$, Sourav $\left.\mathrm{V}_{2}\right)$, Shatabdi $\left(\mathrm{V}_{3}\right)$ and Prodip $\left(\mathrm{V}_{4}\right)$ and four levels of nitrogen viz; 0 $\left(\mathrm{N}_{0}\right), 60\left(\mathrm{~N}_{1}\right), 110\left(\mathrm{~N}_{2}\right)$ and $160\left(\mathrm{~N}_{3}\right) \mathrm{kg} \mathrm{N} \mathrm{ha}^{-1}$. The experiment was laid out in a split-split plot design with three replication. The plot size was $3 \mathrm{~m} \times 4 \mathrm{~m}$. Triple super phosphate (TSP), muriate of potash (MP) and gypsum were applied to the plots at the rate of $180,50,120 \mathrm{~kg} \mathrm{ha}^{-1}$ during final land preparation. Nitrogenous fertilizer was applied as per treatment in two installments; two-third at the time of final land preparation and one-third at 27 days after sowing (DAS). All the applied fertilizers were thoroughly mixed to the soil. Seeds were sown in $25 \mathrm{~cm}$ apart rows opened by specially made an iron hand tine. After sowing the seeds were covered with soil and slightly pressed by hands. Intercultural operation was done as and when necessary.

Grain and straw samples were collected from each plot. Approximately $10 \mathrm{~g}$ of samples of each plot were preserved separately in polythene bags for determination of grain and straw nitrogen contents as well as protein contents. Nitrogen content in wheat grain and straw was determined by the standard micro-kjeldahl method (Total nitrogen estimation method, AOCA 1980). The samples were oven-dried at $65^{\circ} \mathrm{C}$ overnight and grinded with a grinding machine. Wheat grain and straw samples of $0.1 \mathrm{~g}$ were digested with $8 \mathrm{ml}$ of concentrated $\mathrm{H}_{2} \mathrm{SO}_{4}$ in presence of one Kjel-tab and two glass beads in a $75 \mathrm{ml}$ Kjeldahl flask. The sample mixture was heated at $370^{\circ} \mathrm{C}$ for an hour over a preheated heater. After completion of digestion, the flask was cooled at room temperature. For performing distillation, $10 \mathrm{ml}$ of the diluted sample mixture was taken in a Buchi distillation unit with $10 \mathrm{ml}$ of $40 \% \mathrm{NaOH}$. The distillate was collected in $10 \mathrm{ml} 2 \%$ boric acid containing two drops of mixed indicator.The collected distillate in boric acid was titrated with 0.01 N HCI. A blank was run simultaneously to avoid the nitrogen either already present in chemicals or atmospheric nitrogen absorbed during digestion. Then nitrogen percentage was calculated by the following formula with the help of help of titration value.

$\% \mathrm{~N}=\frac{0.014 x \text { Normality of HCI }(0.01 N)}{10} \times \frac{v}{g}=0.0105 \times \frac{v}{g}$

Here, $v=$ Final volume of HCI, $g=$ weight of sample in $\mathrm{g}$.

Protein content of grain and straw was determined by multiplying the nitrogen content of grain and straw by 5.83 and 6.25 , respectively. The result was expressed in percentage. After harvesting, crop of each plot was dried separately for four days. After that, threshing, cleaning and drying of grains were done plot-wise. Then the yields of grain and straw of each plot were recorded and the yields were then converted to hectare basis. The data recorded were compiled and tabulated for statistical analysis. The data were analyzed statistically using the analysis of variance technique and the mean differences among the treatments were adjudged by new Duncan's Multiple Range Test (DMRT) (Gomez and Gomez, 1984) with the help of MSTAT software.

\section{Result and Discussion}

\section{Nitrogen content (\%) in wheat grain}

Nitrogen content in grain differ significantly due to variety. The highest nitrogen content in grain was observed in Prodip and the lowest one in Sourav (Table1). Nitrogen content in grain was significantly influenced by different levels of nitrogen . The highest nitrogen percentage in grain was noticed at $160 \mathrm{~kg} \mathrm{~N}^{-}$

${ }^{1}$ followed by 110 and $60 \mathrm{~kg} \mathrm{~N} \mathrm{ha}^{-1}$ (Table1). Sowing method significantly influenced the nitrogen content in 
grain. The highest nitrogen conten in grain was observed in bed sowing system and the lowest one in conventional system of sowing (Table 1). The interaction effect of sowing method and variety had not significant on grain nitrogen content. The highest nitrogen content in grain was observed in Prodip in bed sowing system followed by Shatabdi and Protiva and the lowest one was observed in Sourav in conventional sowing system (Table 2). The interaction effect of sowing method and nitrogen level was significant for nitrogen content in grain. The highest nitrogen content in grain was found in bed sowing method at $160 \mathrm{~kg} \mathrm{~N} \mathrm{ha}^{-1}$ and the lowest one was found in control treatment (Table 3 ).

Table 1. Effect of variety on quality traits of wheat

\begin{tabular}{|c|c|c|c|c|c|}
\hline Variety & $\begin{array}{c}\text { Nitrogen in } \\
\text { straw }(\%)\end{array}$ & $\begin{array}{c}\text { Nitrogen in } \\
\text { grain }(\%)\end{array}$ & $\begin{array}{l}\text { Protein in } \\
\text { straw }(\%)\end{array}$ & $\begin{array}{l}\text { Protein in } \\
\text { grain }(\%)\end{array}$ & $\begin{array}{c}\text { Grain } \\
\text { yield } \\
\left(\mathbf{t ~ h a} \mathbf{~ h a}^{-1}\right)\end{array}$ \\
\hline $\mathbf{V}_{1}$ & $0.285 \mathrm{c}$ & $2.081 \mathrm{a}$ & $1.840 \mathrm{~b}$ & $12.120 \mathrm{~b}$ & $2.49 \mathrm{~d}$ \\
\hline $\mathbf{V}_{2}$ & $0.295 \mathrm{~b}$ & $2.054 \mathrm{a}$ & $1.867 \mathrm{~b}$ & $11.634 \mathrm{c}$ & $2.86 \mathrm{c}$ \\
\hline $\mathbf{V}_{3}$ & $0.310 \mathrm{~b}$ & 2.087 as & $1.921 \mathrm{~b}$ & $12.205 \mathrm{ab}$ & $3.01 \mathrm{~b}$ \\
\hline $\mathbf{V}_{4}$ & $0.387 \mathrm{a}$ & $2.140 \mathrm{a}$ & $2.441 \mathrm{a}$ & $12.301 \mathrm{a}$ & $3.14 \mathrm{a}$ \\
\hline Nitrogen level & $\begin{array}{c}\text { Nitrogen in } \\
\text { straw }(\%)\end{array}$ & $\begin{array}{c}\text { Nitrogen in } \\
\text { grain }(\%)\end{array}$ & $\begin{array}{l}\text { Protein in } \\
\text { straw }(\%)\end{array}$ & $\begin{array}{l}\text { Protein in } \\
\text { grain }(\%)\end{array}$ & $\begin{array}{c}\text { Grain } \\
\text { yield } \\
(\mathrm{t} \mathrm{ha-1})\end{array}$ \\
\hline $\mathbf{N}_{0}$ & $0.235 \mathrm{~d}$ & $1.967 \mathrm{~d}$ & $1.428 \mathrm{~d}$ & $11.260 \mathrm{~d}$ & $1.78 \mathrm{~d}$ \\
\hline $\mathbf{N}_{1}$ & $0.249 \mathrm{c}$ & $1.989 \mathrm{c}$ & $1.567 \mathrm{c}$ & $11.615 \mathrm{c}$ & $2.76 \mathrm{c}$ \\
\hline $\mathbf{N}_{2}$ & $0.361 \mathrm{~b}$ & $2.141 \mathrm{~b}$ & $2.201 \mathrm{~b}$ & $12.425 \mathrm{~b}$ & $3.34 \mathrm{~b}$ \\
\hline $\mathbf{N}_{3}$ & $0.464 \mathrm{a}$ & $2.250 \mathrm{a}$ & $2.860 \mathrm{a}$ & $12.989 \mathrm{a}$ & $3.61 \mathrm{a}$ \\
\hline $\begin{array}{l}\text { Sowing } \\
\text { method }\end{array}$ & $\begin{array}{c}\text { Nitrogen in } \\
\text { straw }(\%)\end{array}$ & $\begin{array}{c}\text { Nitrogen in } \\
\text { grain }(\%)\end{array}$ & $\begin{array}{l}\text { Protein in } \\
\text { straw }(\%)\end{array}$ & $\begin{array}{l}\text { Protein in } \\
\text { grain }(\%)\end{array}$ & $\begin{array}{c}\text { Grain } \\
\text { yield } \\
\left(\mathrm{t} \mathrm{ha}^{-1}\right)\end{array}$ \\
\hline $\mathbf{S}_{1}$ & 0.301 & 2.050 & 1.878 & 11.964 & 2.77 \\
\hline $\mathbf{S}_{2}$ & 0.362 & 2.145 & 2.256 & 12.481 & 2.98 \\
\hline $\mathbf{L S}$ & 0.05 & 0.01 & 0.01 & 0.01 & 0.01 \\
\hline $\mathrm{CV} \%$ & 0.41 & 3.92 & 5.01 & 0.61 & 9.05 \\
\hline
\end{tabular}

In a column, figures having similar letter(s) or without letter(s) do not differ significantly as per DMRT. 
J. Environ. Sci. \& Natural Resources, 5(1): 267-272, 2012

Table 2. Interaction effect of sowing method and variety on quality traits and yield of wheat

\begin{tabular}{|c|c|c|c|c|c|}
\hline $\begin{array}{c}\text { Sowing } \\
\text { method } \times \\
\text { Variety }\end{array}$ & $\begin{array}{c}\text { Nitrogen in } \\
\text { straw (\%) }\end{array}$ & $\begin{array}{c}\text { Nitrogen in } \\
\text { grain }(\%)\end{array}$ & $\begin{array}{c}\text { Protein in } \\
\text { straw (\%) }\end{array}$ & $\begin{array}{c}\text { Protein in } \\
\text { grain (\%) }\end{array}$ & $\begin{array}{c}\text { Grain } \\
\text { yield } \\
\left(\mathbf{t ~ h a}^{-1}\right)\end{array}$ \\
\hline $\mathbf{S}_{\mathbf{1}} \times \mathbf{V}_{\mathbf{1}}$ & $0.278 \mathrm{~d}$ & 2.035 & $1.667 \mathrm{~d}$ & $11.895 \mathrm{~d}$ & $2.29 \mathrm{f}$ \\
$\mathbf{S}_{\mathbf{1}} \times \mathbf{V}_{\mathbf{2}}$ & $0.281 \mathrm{~cd}$ & 1.936 & $1.756 \mathrm{~cd}$ & $11.315 \mathrm{e}$ & $2.81 \mathrm{de}$ \\
$\mathbf{S}_{\mathbf{1}} \times \mathbf{V}_{\mathbf{3}}$ & $0.294 \mathrm{~b}$ & 2.078 & $1.825 \mathrm{bc}$ & $12.115 \mathrm{c}$ & $2.94 \mathrm{c}$ \\
$\mathbf{S}_{\mathbf{1}} \times \mathbf{V}_{\mathbf{4}}$ & $0.315 \mathrm{~b}$ & 2.085 & $1.947 \mathrm{bc}$ & $12.189 \mathrm{bc}$ & $3.04 \mathrm{bc}$ \\
$\mathbf{S}_{\mathbf{2}} \times \mathbf{V}_{\mathbf{1}}$ & $0.319 \mathrm{~b}$ & 2.114 & $2.010 \mathrm{~b}$ & $12.312 \mathrm{ab}$ & $2.69 \mathrm{e}$ \\
$\mathbf{S}_{\mathbf{2}} \times \mathbf{V}_{\mathbf{2}}$ & $0.310 \mathrm{~b}$ & 2.123 & $1.967 \mathrm{bc}$ & $11.967 \mathrm{~d}$ & $2.92 \mathrm{~cd}$ \\
$\mathbf{S}_{\mathbf{2}} \times \mathbf{V}_{\mathbf{3}}$ & $0.312 \mathrm{~b}$ & 2.110 & $1.989 \mathrm{~b}$ & $12.321 \mathrm{ab}$ & $3.07 \mathrm{~b}$ \\
$\mathbf{S}_{\mathbf{2}} \times \mathbf{V}_{\mathbf{4}}$ & $0.456 \mathrm{a}$ & 2.131 & $2.904 \mathrm{a}$ & $12.441 \mathrm{a}$ & $3.25 \mathrm{a}$ \\
\hline $\mathbf{L S}$ & 0.01 & $\mathrm{NS}$ & 0.01 & 0.01 & $\mathrm{NS}$ \\
\hline $\mathbf{C V} \%$ & 0.41 & 3.92 & 5.01 & 0.61 & 9.05 \\
\hline
\end{tabular}

Table 3. Interaction effect of sowing method and $\mathrm{N}$ rates on quality traits and yield of wheat

\begin{tabular}{|c|c|c|c|c|c|}
\hline $\begin{array}{c}\text { Sowing } \\
\text { method } \times \mathbf{N} \\
\text { level }\end{array}$ & $\begin{array}{c}\text { Nitrogen in } \\
\text { straw }(\%)\end{array}$ & $\begin{array}{c}\text { Nitrogen in } \\
\text { grain }(\%)\end{array}$ & $\begin{array}{l}\text { Protein in } \\
\text { straw }(\%)\end{array}$ & $\begin{array}{l}\text { Protein in } \\
\text { grain }(\%)\end{array}$ & $\begin{array}{c}\text { Grain } \\
\text { yield } \\
\left(\mathrm{t} \mathrm{ha} \text { ha }^{-1}\right)\end{array}$ \\
\hline$S_{1} \times N_{0}$ & $0.215 \mathrm{~h}$ & $1.878 \mathrm{~d}$ & $1.350 \mathrm{e}$ & $10.956 \mathrm{~g}$ & $1.74 \mathrm{e}$ \\
\hline$S_{1} \times N_{1}$ & $0.241 \mathrm{~g}$ & $1.945 \mathrm{~d}$ & $1.507 \mathrm{de}$ & $11.378 \mathrm{f}$ & $2.69 \mathrm{~d}$ \\
\hline $\mathrm{S}_{1} \times \mathrm{N}_{2}$ & $0.325 \mathrm{~d}$ & $2.089 \mathrm{ab}$ & $2.067 \mathrm{c}$ & $12.201 \mathrm{c}$ & $3.22 \mathrm{c}$ \\
\hline $\mathbf{S}_{1} \times \mathbf{N}_{3}$ & $0.384 \mathrm{~b}$ & $2.241 \mathrm{a}$ & $2.315 \mathrm{~b}$ & $13.021 \mathrm{a}$ & $3.42 \mathrm{bc}$ \\
\hline $\mathbf{S}_{2} \times \mathbf{N}_{0}$ & $0.246 \mathrm{f}$ & $2.056 \mathrm{abc}$ & $1.524 \mathrm{~d}$ & $11.535 \mathrm{e}$ & $1.81 \mathrm{e}$ \\
\hline $\mathrm{S}_{2} \times \mathrm{N}_{1}$ & $0.273 \mathrm{e}$ & $2.027 \mathrm{bcd}$ & $1.656 \mathrm{~d}$ & $11.856 \mathrm{~d}$ & $2.84 \mathrm{~d}$ \\
\hline $\mathbf{S}_{2} \times \mathbf{N}_{2}$ & $0.369 \mathrm{c}$ & $2.167 \mathrm{ab}$ & $2.301 \mathrm{~b}$ & $12.645 \mathrm{~b}$ & $3.48 \mathrm{~b}$ \\
\hline $\mathbf{S}_{2} \times \mathbf{N}_{3}$ & $0.536 \mathrm{a}$ & $2.245 \mathrm{a}$ & $3.356 \mathrm{a}$ & $13.088 \mathrm{a}$ & $3.81 \mathrm{a}$ \\
\hline $\mathbf{L S}$ & 0.01 & 0.05 & 0.01 & 0.01 & 0.05 \\
\hline $\mathrm{CV} \%$ & 0.41 & 3.92 & 5.01 & 0.61 & 9.05 \\
\hline
\end{tabular}

In a column, figures having similar letter(s) or without letter(s) do not differ significantly as per DMRT.

\section{Nitrogen content (\%) in wheat straw}

Nitrogen content in straw was significant due to variety. The highest nitrogen content in straw was noted in Prodip and the lowest in Protiva (Table1). Nitrogen content in straw was significantly influenced by different levels of nitrogen. The highest nitrogen percentage in straw was observed at $160 \mathrm{~kg}$ $\mathrm{N} \mathrm{ha}^{-1}$ followed by 110 and $60 \mathrm{~kg} \mathrm{~N} \mathrm{ha}^{-1}$. The lowest nitrogen content in straw was noted at control treatment (Table 1). Sowing method had significant effect on nitrogen content in straw. The highest nitrogen content in straw was noticed in bed sowing system followed by conventional system (Table1). The interaction effect of sowing method and variety had significant effect on nitrogen content in straw. The highest nitrogen content in straw was noted in Prodip in bed sowing system. The lowest nitrogen content in straw was found in Protiva in conventional sowing method (Table 2). Combined effect of sowing method and nitrogen level had significant effect on nitrogen content in straw. The highest nitrogen content in straw was found in bed sowing method at 
$160 \mathrm{~kg} \mathrm{~N} \mathrm{ha}^{-1}$ and the lowest one was found in control treatment (Table 3).

\section{Protein content in wheat grain (\%)}

Protein content in grain varied significantly due to variety. The highest protein content in grain was found in Prodip (Table 1). Grain protein content significantly influenced by different levels of nitrogen. The highest protein content was observed at $160 \mathrm{~kg} \mathrm{~N}$ $\mathrm{ha}^{-1}$ followed by 110 and $60 \mathrm{~kg} \mathrm{~N} \mathrm{ha}^{-1}$ and the lowest protein content in grain was recorded at control treatment (Table 1). Sowing method had significant effect on nitrogen content in grain. The highest protein content in grain was noticed in bed sowing system followed by conventional planting system (Table 1).The interaction effect of sowing method and variety had significant effect on grain protein content. The highest protein content in grain was found in Prodip in bed sowing system and the lowest one was found in Sourav in conventional sowing system (Table 2). The interaction effect of sowing method and nitrogen was found significant on grain protein content. The highest protein content was noticed in bed sowing system at $160 \mathrm{~kg} \mathrm{~N} \mathrm{ha}^{-1}$ and the lowest was found in conventional sowing system at control treatment (Table 3).

\section{Protein content in wheat straw (\%)}

The difference in straw protein content due to variety was statistically significant. The highest protein in straw was obtained from Prodip followed by Shatabdi, Sourav and Protiva (Table 1). Protein content in straw was significantly influenced by different levels of nitrogen. The highest straw protein was recorded at $160 \mathrm{~kg} \mathrm{~N} \mathrm{ha}{ }^{-1}$ and the lowest value was found in control treatment (Table 1). sowing method had significant effect on protein content. The highest straw protein was found in bed sowing method followed by conventional sowing method (Table 1). The interaction effect of sowing method and variety on protein content in straw was significant. The highest protein content in straw was given by the treatment combination of bed sowing and Prodip and the lowest one was given by the treatment combination of conventional sowing and Protiva (Table 2). The interaction effect of sowing method and nitrogen level had significant effect on straw protein content. The highest straw protein content was found in bed sowing system at $160 \mathrm{~kg} \mathrm{~N} \mathrm{ha}^{-1}$ and the lowest value for straw protein content was noted in conventional sowing method at control treatment (Table 3).

\section{Grain yield ( $\mathrm{t} \mathrm{ha} \mathrm{h}^{-1}$ )}

Sowing method had significant effect on grain yield. The highest grain yield ( $2.98 \mathrm{t} \mathrm{ha}^{-1}$ ) was noted from bed sowing method and the lowest one $\left(2.77 \mathrm{t} \mathrm{ha}^{-1}\right)$ was obtained from conventional method of sowing (Table 1). The highest grain yield in bed sowing system was due to the maximum tillers plant ${ }^{-1}$, highest no of grains spike ${ }^{-1}$ and higher 1000-grain weight. Connor et al. (2003) reported that bed sowing showed significantly higher grain yield as compared to flat sowing. Talukder (2004) also reported that bed sowing method showed significantly higher grain yield (3.98 t $\mathrm{ha}^{-1}$ ) than conventional tillage. The differences in grain yield due to variety was statistically significant. Prodip produced the maximum grain yield ( $3.14 \mathrm{t} \mathrm{ha}^{-1}$ ) whereas the minimum one $\left(2.49 \mathrm{t} \mathrm{ha}^{-1}\right)$ was produced by the variety Protiva (Table 1 ). The maximum grain yield in Prodip mainly resulted due to the maximum expression of important yield attributes. The minimum grain yield in Protiva mainly associated with lower number of effective tillers plant ${ }^{-1}$, lower number of grains spike ${ }^{-1}$ etc. Nitrogen levels had significant effect on grain yield. The highest grain yield (3.61) was recorded at $160 \mathrm{~kg} \mathrm{~N} \mathrm{ha}^{-1}$ and the lowest one (1.78 $\mathrm{t} \mathrm{ha}^{-1}$ ) was obtained from control treatment (Table 1). Hossain et al. (2005) reported that grain yield showed significant increased with each increase of $\mathrm{N}$ rate. Similar trends were also agreement with Tripathi et al. (2002); Yadav et al. (2005). The result revealed that as the nitrogen level increased, all yield contributing characters increased which in turn gave higher grain yield. On the other hand, higher grain yield in higher nitrogen doses were attributed by increased number of spikes $\mathrm{m}^{-2}$, number of grains spike $^{-1}$ and 1000-grain weight. Significant effect was not observed in respect of grain yield due to the interaction of sowing method and variety. The maximum grain yield ( $3.25 \mathrm{t} \mathrm{ha}^{-1}$ ) was found in Prodip in bed planting system and the minimum one $\left(2.29 \mathrm{tha}^{-1}\right)$ was observed in Protiva in conventional sowing system (Table 2). The interaction effect between sowing method and nitrogen level on grain yield was statistically significant. The highest grain yield (3.81 $\mathrm{t} \mathrm{ha}^{-1}$ ) was recorded from bed sowing method at $160 \mathrm{~kg} \mathrm{~N} \mathrm{ha}^{-1}$ and the lowest one $\left(1.74 \mathrm{t} \mathrm{ha}^{-}\right.$ $\left.{ }^{1}\right)$ was recorded from the conventional sowing method at $0 \mathrm{~kg} \mathrm{~N} \mathrm{ha}^{-1}$ (Table 3).

From the overall discussion of the results of the experiment, it is found that bed sowing is better than conventional one for producing higher yield of wheat. Better performance was noticed at increasing $\mathrm{N}$ rates among all the varieties. The highest value of nitrogen and protein content and was observed at $160 \mathrm{~kg} \mathrm{~N} \mathrm{ha}^{-}$ ${ }^{1}$. Among the varieties, Prodip is the best one for bed sowing system to maximize the production. 


\section{References}

Ahmed, M. and Hossain, S.M.A. 1992. Effect of seed rate, nitrogen fertilization and time of harvest on the seed yield of wheat. Bangladesh Agron. J. 4(1\&2): 35-43.

Anonymous. 1990. Lav Janak Pddhatite Utpadayaner Upaya (In Bangla). Bangladesh Krishi Gobeshona Institute, Gam Gobeshona Kendra, Nashipur, Dinajpur. 5p.

Anonymous. 1999. Performance of bed sown over conventionally sown wheat under rice-wheat cropping system in Bangladesh. BARI (Bangladesh Agricultural Research Institute) Annual Report. BARI, Joydebpur, Gazipiur. 14p.

BARI (Bangladesh Agricultural Research Institute). 2006. Krishi Projukti Hatboi (Hand book of Agrotechnology) (4 ${ }^{\text {th }}$ Edn $)$. Bangladesh Agril. Res. Ins. Joydevpur, Gazipur. pp. 9-15.

Connor, D.J.; Timsina, J. and Humphreys, E. 2003. Prospects for permanent beds for rice-wheat systems. In: Ladha, J.K. et al., (eds). Improving the productivity and sustainability of rice-wheat systems: Issues and Impacts. ASA. Madison, Wisconsin, USA.

DAE. 2006. Department of Agricultural Extension, Ministry of Agriculture, Government of the peoples republic of Bangladesh.

Gomez, K.A. and Gomez, A.A. 1984. Statistical procedures for agricultural research. $2^{\text {nd }}$ Edn. John Willey and Sons, New York. pp. 97-411.
Hossain, M.I.; Meisner, C.; Duxbury, J.M.; Lauren, J.G.; Rahman, M.M.; Meer, M.M. and Rashid, M.H. 2005. Use of raised beds for increasing wheat production in rice-wheat cropping systems. Bed planting course, CIMMYT. Mexico.

Meisner, C.A.; Acevedo, E.; Flores, D.; Sayre, K.D.; Oritz, M.I. and Byerlee, D. 1992. Wheat production and growers practices in the Yaqui Valley. Wheat special report, 6 Mexico. 75p.

Samad, M.A.; Sarker, A.U. and Sarkar, A.R. 1984. Effect of $\mathrm{N}$ application on the growth and yield of wheat. Bangladesh J. Agril. Sci. 11(1): 97-100.

Sayre, K.D. 2003. Bed planting systems: An overview. CIMMYT, Mexico.

Singh, B.G. and Singh. 1989. Effect of nitrogen on wheat cultivar under late sowing condition. Indian J. Agron. 34(3): 387-389.

Talukder, A.S.M.H.M. 2004. Rice-wheatmaize+mungbean cropping sequence in a permanent bed planting system. Paper presented at Internal review Workshop in 2002 at BARI (Bangladesh Agricultural Research Institute), Joydebpur, Gazipur. pp. 31-33.

Tripathi, S.C.; Sayre, K.D.; Kaul, J.N. and Narang, R.S. 2002. Effect of planting methods and $\mathrm{N}$ rates on lodging, morphological characters of culm and yield in spring wheat varieties. Indian, Cereal Res. Communications. 30(3- 4): 431-438.

Yadav, D.S.; Shukla, R.P.; Sushant and Kumer, B. 2005. Effect of zero tillage and nitrogen level on wheat (Triticum aestivum) after rice (Oryza sativa). Indian J. Agron. 50(1): 52-53. 